\title{
Faktor Risiko Obesitas pada Guru Sekolah Perempuan serta Relevansi dengan PTM Selama Pandemi Covid-19
}

\section{Risk Factors of Obesity Among Female School Teachers and Relevance to Non- Communicable Diseases During the Covid-19 Pandemic}

Agus Hendra Al Rahmad*1

ABSTRAK

Latar Belakang: Prevalensi obesitas didunia semakin tinggi, sehingga menjadi suatu masalah kesehatan yang sangat serius. Beberapa faktor yang berkontribusi terhadap masalah obesitas adalah peningkatan asupan kalori termasuk konsumsi junk food dan sedentari, serta rendahnya aktivitas fisik. Guru sekolah merupakan salah satu unsur tenaga kerja yang paling penting dalam meningkatkan indeks pembangunan manusia, sehingga perlu dilakukan analisis faktor resiko obesitas. Guru dengan permasalahan obesitas yang tinggi dapat menurunkan prestasi dalam pembangunan bangsa dan negara.

Tujuan: Untuk menentukan faktor-faktor risiko obesitas pada guru wanita serta beberapa masalah kesehatan tidak menular selama masa pandemi Covid-19

Metode: Penelitian kuantitatif ini menggunakan desain cross-sectional, yang dilakukan pada 270 guru sekolah wanita, sampel diambil secara purposif sampling. Data berat badan, tinggi badan, lingkar pinggang dilakukan penguran mandiri. Data tekanan darah juga dicatat oleh partisipan, termasuk data diabetes, kolesterol, radang sendi, jantung koroner. Sedangkan data nilai IMT dihitung oleh peneliti. Pengumpulan data menggunakan kuesioner yang disebarkan dari Google Form. Analisis statistik menggunakan uji Chi-Square dan Regressi Logistic.

Hasil: Hasil penelitian menunjukkan faktor risiko obesitas pada guru sekolah wanita adalah usia, lingkar pinggang, konsumsi junk food, jenis diet serta aktivitas fisik $(p<0.05)$, dengan prediktor utama adalah konsumsi junk food $(O R=3.2)$. Selain itu, obesitas pada wanita sangat berkaitan dengan beberapa penyakit tidak menular seperti hipertensi dan radang sendi.

Kesimpulan: faktor risiko utama penyebab tingginya prevalensi obesitas pada guru sekolah wanita di Kota Banda Aceh yaitu akibat kebiasaan konsumsi junk food selama pandemi Covid-19, serta sangat berkaitan dengan masalah kesehatan seperti hipertensi dan radang sendi.

Kata kunci: Aktivitas Fisik, Covid-19, Junk Food, Guru Wanita, Obesitas, Pandemi

\section{ABSTRACT}

Background: The prevalence of obesity in the world is getting higher, so it becomes a severe health problem. Some factors that contribute to the problem of obesity are increased calorie intake, including the consumption of junk food and sedentary, and low physical activity. School teachers are one of the most crucial labor elements in improving the human development indeks, so it is necessary to analyze the risk factors for obesity. Teachers with high obesity problems can reduce the development index.

Objectives: The study aims to determine the risk factors for obesity in female teachers as well as some non-communicable health problems during the Covid-19 pandemic.

Methods: This quantitative study uses a cross-sectional design, which was conducted on 270 female school teachers; the sample was taken by purposive sampling. Participants has self reported measured weight, height, waist circumference data. Blood pressure data were also recorded by participants, including data on diabetes, cholesterol, arthritis, coronary heart disease. While the BMI value data is calculated by the researcher Data collection using a questionnaire distributed from Google Form. Statistical analysis using test Chi-Square and Logistic Regression.

Results: The results showed risk factors for obesity in female school teachers were age, waist circumference, consuming junk food, type of diet and physical activity $(p<0.05)$, with the main predictor being consumption junk food $(O R=3.2)$. Also, obesity in women is closely related to several non-communicable diseases such as hypertension and arthritis.

Conclusions: The main risk factors that cause the high prevalence of obesity in female school teachers in Banda Aceh City are due to consumption habits junk food during the Covid-19 pandemic, and are strongly related to health problems such as hypertension and arthritis.

Keywords: Covid-19, Physical Activity, Junk Food, Female Teacher, Obesity, Pandemic

\footnotetext{
*Korespondensi:

agus.hendra.alr@poltekkesaceh.ac.id

Agus Hendra Al Rahmad
} 


\section{PENDAHULUAN}

Pandemi Corona Virus Disease 2019 (Covid-19) masih terus berlangsung, tetapi trend penyebaran dan infeksinya secara global sudah mulai menurun ${ }^{1}$. Hal itu terjadi karena banyak negara yang menerapkan kebijakan lockdown ${ }^{2}$, dan juga karantina wilayah secara ketat ${ }^{3}$, selain itu adanya dampak positif dari kerja sama masyarakat melalui pendekatan stay at home $e^{4}$. Terbukti, beberapa negara yang baik dalam penanganannya seperti di Eropa, Asia maupun Asia Tenggara mengumumkan bahwa terdapat trend positif dalam penurunan infeksi Covid-195,6

Walaupun secara global terjadi penurunan, namun di Indonesia COVID-19 terus meningkat menjadi 41,431 orang, dengan pasien sembuh $(16,243$ orang), serta terdapat 2,276 orang dengan kasus meninggal?. Beberapa hasil penelitian telah memprediksikan, bahwa memungkinkan banyak negara-negara di dunia yang akan terbebas dari pandemi antara bulan Mei sampai Juni tahun 2020. Namun demikian, masih terdapat satu kekhawatiran banyak pakar kesehatan di dunia sebagai pengganti Covid-19, yaitu bentuk bahaya kesehatan yang sangat sulit dicegah ${ }^{8}$. Pandemi Covid-19 telah membuat perubahan pola kehidupan pada berbagai sektor termasuk aktivitas serta pola konsumsi yang tidak terkontrol, seperti sedentary dan makan makanan cepat saji ${ }^{9}$. Faktor-faktor tersebut bila berlangsung secara berkesinambungan, maka hal tersebut memungkinkan terjadinya risiko obesitas.

Kegemukan serta obesitas dianggap sebagai masalah kesehatan masyarakat utama di negara maju dan berkembang ${ }^{10}$. Badan kesehatan dunia (WHO) pada tahun 2012 telah melaporkan bahwa satu dari enam orang dewasa mengalami obesitas dan sekitar 2.8 juta orang meninggal setiap tahun karena kelebihan berat badan atau pernah mengalami obesitas ${ }^{11}$. Negara-negara berkembang seperti Indonesia, tingkat prevalensi obesitas meningkat sangat signifikan serta begitu mengkhawatirkan ${ }^{12}$, data menunjukkan sebesar $44.4 \%$ penduduk di Indonesia pada usia di atas 18 tahun mengalami kegemukan serta obesitas yang ditemukan pada wanita. Beberapa daerah di Indonesia, menunjukkan proporsi yang cukup tinggi terhadap prevalensi kegemukan dan obesitas seperti Sulawesi Utara (46.5\%), DKI Jakarta (45.4\%), dan tertinggi ketiga diikuti oleh Kalimantan Timur (44.2\%), sedangkan Provinsi Aceh menduduki posisi kesepuluh dengan prevalensi sebesar $38.3 \%^{13}$.

Pekerjaan sebagai guru telah menuntut kesetaraan gender, sehingga para perempuan banyak yang memilih sebagai profesi guru ${ }^{14}$. Kondisi ini telah membentuk banyak perempuan yang memilih profesi tersebut untuk meningkatkan status taraf sosial ekonomi keluarga mereka ${ }^{15}$. Sehingga dengan demikian, profesi guru adalah mewakili salah satu sektor tenaga kerja yang paling penting pada negara-negara maju dan berkembang ${ }^{16}$.

Pandemi Covid-19 telah membuat perubahan pola kehidupan pada berbagai sektor termasuk aktivitas serta pola konsumsi yang tidak terkontrol ${ }^{9}$. Guru dalam masa pandemi sering kewalahan dengan banyak tugas seperti proses mengajar, melakukan rapat secara daring serta pengembangan karirnya dan hal tersebut dapat mengakibat stres pada mereka ${ }^{17}$. Sering kali, kesehatan mereka terpengaruh karena peran ganda yang mereka lakukan; yaitu sebagai bagian keluarga dan bekerja sesuai profesi namun dilakukan di rumah (stay at home). Mereka secara umum rentan dengan berbagai penyakit tidak menular seperti penyakit jantung, diabetes dan hipertensi ${ }^{18}$, selain itu menurut Elmajnoun et al. ${ }^{19}$, akibat pandemi Covid-19 orang-orang sudah jarang melakukan aktivitas fisik dan perubahan pola kehidupan pada berbagai sektor termasuk pola konsumsi yang tidak terkontrol. Hal tersebut tentunya diperburuk dengan diberlakukannya jam kerja di rumah (Work From Home). Lebih lanjut menurut Ammar et $\mathrm{al}^{20}$, menyimpulkan ternyata selama masa stay at home pada masyarakat Asia, Afrika dan Eropa umumnya mereka lebih banyak melakukan aktivitas ringan dengan peningkatan waktu istirahat (duduk dan berbaring) lebih lama. Selain itu, pola konsumsi mereka tidak terkontrol baik dari segi jenis, frekuensi maupun makanan tidak sehat serta penngkatan terhadap konsumsi alkohol. Beberapa studi lain juga melaporkan bahwa masa pandemic Covid-19 telah menurunkan kinerja oleh para guru sekolah, namun berupaya tetap melakukan pembelajaran secara daring melalui metode STEM ${ }^{21}$, di Indonesia menurut Purwanto et $\mathrm{al}^{20}$ juga mengemukakan bahwasanya pandemic tersebut telah menurunkan motivasi guru serta meningkatnya biaya listrik dan internet, selain itu memungkinkan terhada masalah keamanan data.

Berdasarkan latar belakang permasalahan diatas tentang risiko obesitas pada guru sekolah sejak diberlakukan social distancing, maka perlu dilakukan suatu penelitian terkait dengan faktor risiko obesitas pada guru wanita dan masalah penyakit tidak menular selama pandemi Covid-19. Tingginya kasus obesitas di Kota Banda Aceh umumnya pada wanita diatas usia 18 tahun memungkinkan meningkatkan masalah penyakt tidak menular. Guru sekolah merupakan salah satu unsur tenaga kerja yang paling penting dalam meningkatkan indeks pembangunan manusia, sehingga perlu dilakukan analisis faktor resiko obesitas. Guru dengan permasalahan obesitas yang tinggi dapat menurunkan prestasi dalam pembangunan bangsa dan negara. Adapun penelitian ini bertujuan untuk menentukan faktor-faktor risiko obesitas pada guru wanita serta beberapa masalah kesehatan tidak menular selama masa pandemi Covid-19 di Kota Banda Aceh.

\section{METODE}

Penelitian menggunakan desain cross-sectional yang studinya dilakukan secara deskriptif analitik. Sampel diambil berdasarkan hasil purposif sampling, dan terpilih sebanyak 270 guru sekolah wanita dengan waktu penelitian sejak Maret sampai Juni 2020 di Kota Banda Aceh. Sampel yang terpilih merupakan hasil keinginan untuk berpartisipasi dibuktikan dengan mengisi kuesioner secara lengkap dengan tujuan mengidentifikasi populasi obesitas dan tidak obesitas pada guru sekolah wanita. Kriteria inklusi adalah wanita berusia antara $25-55$ tahun, aktif sebagai guru sekolah, dapat bekerjasama 
dengan baik selama penelitian berlangsung. Sedang kriteria ekklusi yaitu guru bukan pegawai negeri.

Izin dari pihak sekolah serta persetujuan telah dilakukan. Kuesioner yang digunakan dirancang oleh peneliti dan telah sesuai berdasarkan hasil uji kuesioner pada beberapa sampel. Pengumpulan data meliputi pengisian angket kuesioner melalui google form yang diedarkan secara daring, yaitu data karakteristik, pola konsumsi (junk food), jenis diet, aktivitas, dan beberapa riwayat penyakit tidak menular. Pengumpulan data aktivitas fisik menggunakan Global Physical Activity Questionnaire (GPAQ), dan data riwayat penyakit tidak menular dikumpulkan berdasarkan gejala/hasil pengukuran terakhir/ diagnosa dokter atau tenaga kesehatan. Sedangkan data antropometri dan data tekanan darah, proses pengukuran dilakukan oleh partisipan serta mengisikan ke lembaran angket yang telah disediakan. Penyebaran link kuesioner melalui facebook, WhatsApp, dan berkunjung ke sekolah-sekolah untuk menjumpai guru piket sehingga bisa meneruskan kepada guru-guru lainnya.

Berat badan (dalam $\mathrm{kg}$ ) diukur menggunakan timbangan digital yang diletakan pada permukaan datar, dan pengukuran tinggi badan (dalam $\mathrm{cm}$ ) menggunakan pita ukur yang terpasang pada dinding sejajar dan permukaan rata. Kedua pengukuran ini diambil dengan subjek mengenakan pakaian minimal dan tanpa alas kaki. Lingkar pinggang (dalam $\mathrm{cm}$ ) diukur dengan mengukur jarak sekitar pinggang setengah inci di atas pusar menggunakan pita pengukur plastik. Menurut Hastuti et al. ${ }^{22}$, lingkar pinggang diatas $80.0 \mathrm{~cm}$ mengindikasikan terdapatnya obesitas abdominal (obesitas sentral) pada wanita. Indeks massa tubuh (BMI) dalam penelitian digunakan sebagai ukuran terhadap kelebihan berat badan dan obesitas, yang dihitung menggunakan persamaan $I M T=\frac{B B}{T B^{2}}$, dimana berat badan dalam $\mathrm{Kg}$ dan tinggi badan dalam satuan meter. Katagori obesitas berdasarkan acuan Kementerian Kesehatan dan WHO yaitu jika IMT di atas $27.0 \mathrm{~kg} / \mathrm{m}^{2}$. Data tekanan darah dikelompokkan menjadi dua yaitu hipertensi jika $\geq 140$ $\mathrm{mmHg}$ dan normal jika $<140 \mathrm{mmHg}{ }^{23}$.

Setelah dilakukan tahapan pengolahan data maka selanjutnya dilakukan analisis secara statistik. Ke semua data dianalisis menggunakan IBM SPSS Statistic (versi 25.0). Kelengkapan dan konsistensi data telah dilakukan pemeriksaan secara univariat untuk mendeskripsikan sebaran data pada masing-masing variabel. Beberapa jenis statistik yang digunakan yaitu distribusi frekuensi, rata-rata dan deviasi. Selanjutnya di lakukan analisis bivariat untuk membandingkan faktor risiko terhadap kejadian obesitas pada guru wanita, yaitu menggunakan uji chi-square. Selain dalam penelitian ini juga dilakukan analisis Regressi Binary Logistic sebagai identifikasi faktor risiko dominan terhadap kejadian obesitas pada tingkat kemaknaan $95 \%$.

Penelitian ini telah dilakukan uji kelaikan etik yang menyatakan bahwa penelitian tidak menyalahi prosedur dan tidak bertentangan dengan nilai-nilai norma kemanusiaan. Uji kelaikan etik diperoleh dari Komisi Etik Penelitian Kesehatan (KEPK) Fakultas Keperawatan USU, dengan nomor: 2181/VI/SP/2020.

\section{HASIL DAN PEMBAHASAN}

Karakteristik partisipan dalam penelitian ini yang berkaitan dengan permasalahan risiko obesitas yaitu meliputi usia, penghasilan, tingkat pendidikan, jenjang guru sekolah, dan pengalaman mengajar selama menjadi guru pada beberapa sekolah di Kota Banda Aceh

Tabel 1. Distribusi guru sekolah wanita berdasarkan karakteristik pekerjaan $(n=270)$

\begin{tabular}{llll}
\hline Karakteristik Guru Sekolah Wanita & Frekuensi & Persen \\
\hline Usia (tahun) & $<30$ tahun & 78 & 28.9 \\
& $30-40$ tahun & 103 & 2 \\
& $40-50$ tahun & 70 & 25.9 \\
& $>50$ tahun & 19 & 7.0 \\
Pendapatan (Rupiah) & $<3,000,000$ & 5 & 1.9 \\
& $3,000,000-5,000,000$ & 66 & 24.4 \\
& $5,000,000-7,000,000$ & 185 & 68.5 \\
Tingkat Pendidikan Guru & $>7,000,000$ & 14 & 5.2 \\
& Diploma 3 & 23 & 8.5 \\
& Sarjana (S1) & 148 & 54.8 \\
& Pasca Sarjana (S2) & 94 & 34.8 \\
& Doktor (S3) & 5 & 1.9 \\
Jenjang Sekolah & SD & 92 & 34.1 \\
& SMP & 88 & 32.6 \\
& SMA & 90 & 33.3 \\
Pengalaman Mengajar & $1-5$ tahun & 80 & 29.6 \\
& $6-10$ tahun & 78 & 28.9 \\
& $11-15$ tahun & 61 & 22.6 \\
& $16-20$ tahun & 32 & 11.9 \\
\hline
\end{tabular}


Berdasarkan hasil penelitian (Tabel 1), diketahui bahwa karakteristik guru berdasarkan usia, ternyata guru yang berpartisipasi dalam penelitian ini berkisar antara 30 - 40 tahun (38.1\%) serta masih terdapat guru yang berusia diatas 50 tahun sebesar $7.0 \%$. Status sosial ekonomi mengacu pada status sosial berdasarkan nilai pendapatan dari BPS yaitu Upah Minimum Propinsi (UMP) yang diukur sebagai total pendapatan dari profesi guru bulanan, hasil diketahui tingkat pendapatan para guru di Kota Banda Aceh, persentase yang lebih besar termasuk baik yaitu umumnya berkisar antara Rp. 5,000,000 - Rp. 7,000,000 per bulan (68.5\%) dengan standar UMP Provinsi Aceh tahun 2020 adalah Rp. 3,165,031. Berkenaan dengan kualifikasi pendidikan, karena guru dipilih sebagai kelompok sasaran, semuanya adalah lulusan perguruan tinggi sehingga mayoritas guru (54.8\%) adalah lulusan sarjana strata 1 (S1) dan sisanya adalah lulusan S2 sebesar $34.8 \%$ dan S3 sebesar 1.9\%, namun demikian masih terdapat $8.5 \%$ guru yang berpendidikan diploma. Selanjutnya juga terlihat, bahwa guru yang mengambil kelas untuk jenjang pendidikan dasar, menengah pertama dan menengah atas hampir mempunyai proporsi yang sama, walaupun guru pada sekolah dasar lebih banyak (34.1\%) yang terlibat sebagai partisipan dalam penelitian ini. Berkenaan dengan pengalaman mengajar, terdapat $29.6 \%$ dari guru memiliki minimal $1-5$ tahun pengalaman mengajar sementara sebesar $18.9 \%$ melaporkan bahwa telah lebih dari 15 tahun bekerja sebagai profesi guru di Kota Banda Aceh.

Tabel 2. Ukuran antropometri dan tekanan darah pada guru wanita di Kota Banda Aceh $(n=270)$

\begin{tabular}{lllll}
\hline Variabel & $\begin{array}{l}\text { Minimum } \\
\text { Maksimum }\end{array}$ & $\begin{array}{l}\text { Rata-rata } \\
\text { Deviasi }\end{array}$ & $\pm \begin{array}{l}\text { Cl:95\% } \\
\text { (Lower - Upper) }\end{array}$ \\
\hline Umur & $25.0-58.0$ & $34.7 \pm 9.24$ & $29.0-38.5$ \\
Berat badan $(\mathrm{kg})$ & $45.2-115.5$ & $65.6 \pm 22.87$ & $57.05-74.13$ \\
Tinggi badan $(\mathrm{cm})$ & $145.5-170.0$ & $160.5 \pm 7.62$ & $158.5-163.6$ \\
IMT $(\mathrm{kg} / \mathrm{m} 2)$ & $21.4-39.1$ & $25.8 \pm 8.58$ & $22.2-29.46$ \\
Lingkar pinggang $(\mathrm{cm})$ & $69.5-130.0$ & $79.3 \pm 10.57$ & $75.0-86.3$ \\
Tekanan darah $(\mathrm{mmHg})$ & $85.0-320.0$ & $114.5 \pm 15.92$ & $110.0-135.5$ \\
\hline
\end{tabular}

Ukuran antropometri pada guru wanita di Kota Banda Aceh, berdasarkan hasil penelitian (Tabel 2) terlihat rata-rata berat badan yaitu $65.6 \mathrm{~kg}$ dan tinggi badan $160.5 \mathrm{~cm}$ dengan IMT yaitu $25.8 \mathrm{~kg} / \mathrm{m}^{2}$, sedangkan rata-rata lingkar pinggang yaitu $79.3 \mathrm{~cm}$. Dengan demikian dapat dideskripsikan bahwa secara umum status gizi pada guru sekolah wanita berdasarkan IMT yaitu mempunyai berat badan lebih atau mengalami kegemukan. Begitu juga dengan kondisi status gizi menurut lingkar pinggang yang menunjukkan mayoritas dari guru sekolah yaitu hampir mengalami obesitas. Selanjutnya berdasarkan hasil ukur tekanan darah, terlihat rata-ratanya yaitu $114.5 \mathrm{mmHg}$ yang mengindikasikan bahwa pada guru wanita mempunyai tekanan darah normal dan memungkinkan risiko terhadap penyakit hipertensi, diabetes dan penyakit jantung lebih kecil.

Tabel 3. Distribusi frekuensi IMT, lingkar pinggang dan tekanan darah pada guru wanita di Kota Banda Aceh $(n=270)$

\begin{tabular}{llll}
\hline Variabel & & Frekuensi & Persen \\
\hline IMT & $<27.0 \mathrm{~kg} / \mathrm{m}^{2}$ & 165 & 61.1 \\
& $\geq 27.0 \mathrm{~kg} / \mathrm{m}^{2}$ & 105 & 38.9 \\
Lingkar pinggang & $\leq 80.0 \mathrm{~cm}$ & 159 & 58.9 \\
& $>80.0 \mathrm{~cm}$ & 111 & 41.1 \\
Tekanan darah & $\leq 140 \mathrm{mmHg}$ & 145 & 53.7 \\
& $>140 \mathrm{mmHg}$ & 125 & 46.3 \\
\hline
\end{tabular}


Tabel 4. Faktor risiko obesitas pada guru sekolah wanita di Kota Banda Aceh

\begin{tabular}{|c|c|c|c|c|}
\hline \multirow{2}{*}{\multicolumn{2}{|c|}{ Faktor Risiko pada Guru Wanita }} & \multicolumn{2}{|c|}{ Kejadian Obesitas } & \multirow{3}{*}{$\begin{array}{l}\text { Nilai } p \\
0.000^{*}\end{array}$} \\
\hline & & \multirow{2}{*}{$\begin{array}{l}\text { Obesitas } \\
16(15.2 \%)\end{array}$} & \multirow{2}{*}{$\begin{array}{l}\text { Tidak Obesitas } \\
62(37.6 \%)\end{array}$} & \\
\hline Usia & $<30$ tahun & & & \\
\hline & $30-40$ tahun & $37(35.2 \%)$ & $66(40.0 \%)$ & \\
\hline & $40-50$ tahun & 42 (40.0\%) & $28(17.0 \%)$ & \\
\hline & $>50$ tahun & $10(9.6 \%)$ & $9(5.4 \%)$ & \\
\hline \multirow[t]{4}{*}{ Pendapatan } & $<3,000,000$ & $2(1.9 \%)$ & $3(1.8 \%)$ & 0.566 \\
\hline & $3,000,000-5,000,000$ & $21(20.0 \%)$ & $45(27.3 \%)$ & \\
\hline & $5,000,000-7,000,000$ & 77 (73.3 \%) & $108(65.5 \%)$ & \\
\hline & $>7,000,000$ & $5(4.8 \%)$ & $9(5.5 \%)$ & \\
\hline \multirow[t]{2}{*}{ Lingkar Pinggang } & $<80 \mathrm{~cm}$ & $42(40.0 \%)$ & $117(70.9 \%)$ & $0.000 *$ \\
\hline & $\geq 80 \mathrm{~cm}$ & $63(60.0 \%)$ & $48(29.1 \%)$ & \\
\hline Konsums & $\overline{Y a}$ & $78(74.3 \%)$ & $94(57.0 \%)$ & $0.006^{*}$ \\
\hline Food & Tidak & 27 (25.7\%) & $71(43.0 \%)$ & \\
\hline \multirow[t]{2}{*}{ Konsumsi Asinan } & $\mathrm{Ya}$ & 34 (32.4 \%) & $68(41.2 \%)$ & 0.183 \\
\hline & Tidak & $71(67.6 \%)$ & $97(58.8 \%)$ & \\
\hline \multirow[t]{3}{*}{ Jenis Diet } & Vegetarian & $6(5.7 \%)$ & $23(13.9 \%)$ & $0.047 *$ \\
\hline & Ovo-vegetarian & $19(18.1 \%)$ & $37(22.4 \%)$ & \\
\hline & Bukan vegetarian & $80(76.2 \%)$ & $105(63.6 \%)$ & \\
\hline \multirow[t]{3}{*}{ Aktivitas Fisik } & Cukup & $32(30.5 \%)$ & $103(62.4 \%)$ & $0.000^{*}$ \\
\hline & Kurang & 62 (59.0\%) & 55 (33.3\%) & \\
\hline & Tidak & 11 (10.5\%) & $7(4.2 \%)$ & \\
\hline
\end{tabular}

* Siginifikan pada $\alpha=5 \%(p<0.05)$

Selanjutnya Tabel 3 menyajikan distribusi IMT, lingkar pinggang dan proporsi tekanan darah pada guru sekolah wanita di Kota Banda Aceh. Terlihat guru sekolah wanita yang mempunyai IMT diatas $27.0 \mathrm{~kg} / \mathrm{m}^{2}$ sebesar $38.9 \%$ dengan lingkar pinggang diatas $80.0 \mathrm{~cm}$ sebesar $41,1 \%$. Begitu juga dengan tekanan darah, terdapat sebesar $46.3 \%$ guru yang mempunyai tekanan darah diatas $140 \mathrm{mmHg}$ atau pernah mengalami riwayat hipertensi.Hasil analisis penelitian yang dilakukan secara bivariat menggunakan uji Chi-Square (Tabel 4), telah menunjukkan bahwa berdasarkan usia maka proporsi kejadian obesitas lebih tinggi pada guru dengan usia 40 50 tahun $(40.0 \%)$ dan mempunyai lingkar pinggang diatas $80 \mathrm{~cm}$ (60.0\%). Selain itu akibat kebiasaan konsumsi junk food $(74.0 \%)$ dan tidak melakukan diet $(76,2 \%)$. Sedangkan proporsi tingginya obesitas pada guru wanita diakibatkan juga oleh kurang baiknya aktivitas fisik (59.0\%) pada guru sekolah wanita di Kota Banda Aceh. Secara statistik menunjukkan bahwa faktor risiko obesitas pada guru adalah faktor usia, lingkar pinggang, konsumsi junk food, program/jenis diet serta aktivitas fisik ( $p<$ 0.05). Sedangkan faktor pendapatan, konsumsi asinan, bukan merupakan faktor risiko obesitas pada guru sekolah wanita di Kota Banda Aceh, $(p>0.05)$ selama masa pandemi Covid-19.

Hasil penelitian telah menunjukkan bahwa faktorfaktor risiko yang berhubungan dengan kejadian obesitas pada guru wanita yaitu usia, lingkar pinggang, konsumsi junk food, jenis diet serta aktivitas fisik selama dalam masa pandemi Covid-19 di Kota Banda Aceh. Sedangkan pendapatan dan konsumsi asinan, dalam studi ini tidak menunjukkan hubungan dengan kejadian obesitas $(p>$ 0.05). Pada variabel usia, obesitas lebih tinggi pada rentang 40 - 50 tahun sedangkan berdasarkan antropometri lingkar pinggang, guru wanita yang mempunyai lingkar pinggang di atas $80 \mathrm{~cm}$ lebih banyak yang mengalami obesitas. Selanjutnya berdasarkan riwayat konsumsi, guru yang mengalami obesitas akibat pernah mengkonsumsi junk food, dan searah dengan tidak melakukan diet juga mempunyai proporsi lebih tinggi mengalami obesitas. Obesitas juga dapat terjadi pada guru wanita yang mempunyai aktivitas yang kurang, ini merupakan akibat dari pola makan yang kurang baik seperti konsumsi junk food yang sangat sering serta faktor usia daripada guru yang kurang memungkinkan untuk melakukan aktivitas fisik.

Seiring bertambahnya usia pada wanita, maka sangat memungkinkan terjadinya peningkatan risiko beberapa penyakit tidak menular seperti diabetes, hipertensi, penyakit kardiovaskular dan obesitas ${ }^{24}$. Beberapa hasil penelitian telah menunjukkan bahwa prevalensi obesitas umumnya terjadi pada usia $40-50$ tahun, seperti hasil penelitian Trisna \& Hamid $^{25}$ yang menemukan bahwa obesitas sentral pada wanita lebih banyak terjadi pada kelompok antara 40 - 50 tahun sebesar 55.8\%. Menurut Hong et al. ${ }^{26}$ wanita-wanita di Asia Tenggara pada usia antara 40 - 59 tahun memungkinkan risiko obesitas lebih tinggi dibandingkan pada wanita dengan usia lebih muda. Kondisi tersebut akibat lambatnya proses metabolisme dalam tubuh pada wanita usia 40 - 59 tahun, diduga hal ini akibat rendahnya aktivitas fisik serta pola konsumsi yang tidak seimbang. Buch et al. ${ }^{27}$, berpendapat bahwa wanita dengan usia lebih tua akan terjadi penurunan jaringan otot serta beberapa perubahan hormon dalam tubuh, sehingga dapat memicu terhadap menumpuknya lemak pada bagian perut.

Berat badan setiap individu sangat tergantung pada berbagai faktor seperti faktor genetik, perilaku, gaya hidup, suku dan sosial ekonomi ${ }^{28}$. Kelebihan berat badan adalah faktor risiko utama terhadap berbagai masalah 
kesehatan. Semakin bertambah berat badan maka semakin besar IMT, dan peningkatan IMT tersebut memungkinkan mengalami risiko obesitas ${ }^{12}$. Dalam penelitian ini tingkat prevalensi obesitas (IMT > 27.0 $\mathrm{kg} / \mathrm{m}^{2}$ ) di kalangan guru sekolah wanita ditemukan sebesar $38.9 \%$. Rocha et al. ${ }^{29}$ melaporkan bahwa tingkat prevalensi kelebihan berat badan atau obesitas menjadi 47.2\% di antara guru menunjukkan obesitas sebagai masalah kesehatan utama di antara guru sekolah.

Kelebihan berat badan (IMT $25-26.9 \mathrm{Kg} / \mathrm{m}^{2}$ ) atau obesitas (IMT $\geq 27 \mathrm{Kg} / \mathrm{m}^{2}$ ) telah dianggap menjadi faktor risiko utama terhadap beberapa penyakit kronis termasuk penyakit jantung koroner, hipertensi, kolesterol, dan diabetes pada masa pandemi Covid-1930. Meningkatkan beberapa prevalensi penyakit tidak menular akibat bertambahnya IMT semakin menambah permasalahan kesehatan akibat stay at home selama pandemi Covid$19^{4}$. Sehingga, berat badan ideal perlu dipertahankan untuk memperkecil risiko obesitas serta mencegah timbulnya penyakit kronis. Pandemi Corona Virus (Covid19) telah mengubah pola dan tatanan kehidupan masyarakat termasuk sektor kesehatan seperti pola makan dan aktivitas yang tidak terkontrol ${ }^{9}$, dan memungkinkan guru-guru menghadapi stres dalam masa pandemi akibat banyaknya kegiatan yang akan diselesaikan di rumah baik sebagai profesi guru maupun yang umumnya sebagai ibu rumah tangga ${ }^{17}$. Mereka umumnya rentan dengan berbagai penyakit tidak menular seperti penyakit jantung, diabetes dan hipertensi ${ }^{18}$.

Selain itu, terdapat dua faktor utama lainnya yang berkaitan dengan obesitas dalam penelitian ini yaitu faktor lingkar pinggang dan peningkatan IMT pada wanita. Lingkar pinggang tidak hanya terkait dengan obesitas, namun menurut Haghighatdoost et al. ${ }^{31}$ dalam penelitiannya telah menunjukkan bahwa ukuran lingkar pinggang merupakan faktor risiko untuk pra-diabetes dan diabetes. Dalam penelitian ini jelas bahwa terdapat guru sekolah wanita yang obesitas dan mempunyai riwayat diabetes. Selain itu juga hasil penelitian yang didapatkan oleh Abtahi et al. ${ }^{32}$ yang menyimpulkan bahwa terdapat hubungan yang kuat antara peningkatan lingkar pinggang dan IMT dengan risiko diabetes pada kalangan guru-guru sekolah.

Di Indonesia, juga telah ditemukan bahwa lingkar pinggang sangat berkaitan dengan peningkatan kadar gula darah (pra-diabetes) sehingga berimplikasi terhadap risiko diabetes ${ }^{33}$. Penderita diabetes mempunyai peluang besar terkena infeksi pernapasan, dan dapat memperparah kondisi kadar gula darah ${ }^{34}$. Komplikasi diabetes dengan covid-19 adalah termasuk penyumbang komorbid terbesar terhadap angka kematian pasien akibat covid-19 di Indonesia setelah TBC dan hipertensi ${ }^{35}$. Hal ini sesuai berdasarkan beberapa studi di Wuhan, China yang menyebutkan $42,3 \%$ dari kematian akibat covid-19 merupakan pasien dengan komplikasi diabetes ${ }^{36}$. Penelitian lain di Wuhan menunjukkan bahwa pada 150 pasien (terdapat 68 kematian dan 82 pasien sembuh), jumlah komorbiditas merupakan sebagai prediktor yang signifikan terhadap kematian pasien ${ }^{37}$. Oleh karena itu, menjaga kebugaran dengan mempertahankan berat badan ideal pada wanita selama masa pandemi Covid-19 sangat penting dilakukan untuk menghindari munculnya risiko penyakit degeneratif. Hal tersebut bisa dilakukan melalui menjaga pola makan dengan menu seimbang, membatasi konsumsi junk food, serta melakukan aktivitas sedang atau ringan baik dalam rumah maupun di luar rumah.

Pendapatan dan konsumsi asinan dalam penelitian ini tidak menunjukkan hubungan dengan terjadinya obesitas pada guru sekolah wanita di Kota Banda Aceh. Menurut Min et al. ${ }^{38}$, masyarakat pada kelompok sosial tertentu di daerah perkotaan, umumnya mempunyai pendapatan yang baik sehingga memungkinkan terjadinya perubahan konsumsi atau pola makan yang berpeluang terhadap meningkatnya penyakit tidak menular, salah satunya yaitu obesitas. Selain itu menurut Rawal et al. ${ }^{39}$, melaporkan dalam studinya di Nepal bahwa orang-orang dewasa yang berasal dari kelompok dengan pengahasilan menengah kebawah memungkinkan juga mengalami kegemukan dan obesitas jika gaya kehidupan kurang baik. Oleh karena itu, pendapatan bukan merupakan faktor langsung terhadap terjadinya obesitas, namun cenderung disebabkan oleh pola atau perilaku yang tidak sehat. Begitu juga dengan konsumsi asinan, Canaud et al. ${ }^{40}$, menyebutkan bahwa tingginya kandungan natrium dapat menyebabkan cairan ekstraseluler meningkat dan mengikat air sehingga memungkinkan mengalami penyakit tidak menular. Namun demikian, pada hasil studi ini hanya sedikit guru yang mengkonsumsi asinan dan mengalami obesitas (32.4\%), selain itu mereka juga sangat jarang mengkonsumsi asinan. Sebaliknya, konsumsi junk food mempunyai frekuensi yang paling sering selama masa pandemi.

Tabel 5. Hasil analisis regresi logistic berganda terhadap risiko obesitas pada guru sekolah wanita di Kota Banda Aceh

\begin{tabular}{llcl}
\hline Faktor Risiko & OR & $\begin{array}{l}\text { Cl:95\% } \\
\text { (Lower-Upper) }\end{array}$ & Nilai p \\
\hline Usia 40-50 tahun & 0.728 & $0.647-1.955$ & 0.109 \\
Lingkar pinggang $\geq 80 \mathrm{~cm}$ & 2.055 & $1.840-2.196$ & $0.000^{*}$ \\
Konsumsi junk food & 3.164 & $1.654-6.085$ & $0.001^{*}$ \\
Jenis diet bukan vegetarian & 0.940 & $0.510-2.719$ & 0.297 \\
Aktivitas fisik kurang & 1.426 & $1.037-3.844$ & $0.013^{*}$ \\
\hline * Siginifikan pada $\alpha=5 \%(\mathrm{p}<0.05)$ & & &
\end{tabular}

Uji lanjut terhadap prediktor utama dalam mengukur faktor risiko obesitas menggunakan analisis regresi logistic berganda (Tabel 5). Hasil penelitian tersebut telah menunjukkan bahwa terdapat tiga faktor risiko sebagai prediktor obesitas pada guru sekolah di Kota Banda Aceh. Ketiga faktor tersebut yaitu lingkar 
pinggang, konsumsi junk food, dan aktivitas fisik ( $p<$ $0.05)$, sedangkan faktor usia dan jenis diet bukan merupakan kandidat terhadap faktor risiko obesitas $(p>$ 0.05) pada guru sekolah wanita di Kota Banda Aceh selama pandemi Covid-19. Hasil penelitian tersebut juga telah mengidentifikasikan bahwa kebiasaan konsumsi junk food merupakan prediktor dominan terhadap kejadian obesitas pada guru sekolah wanita $(O R=3.2$ ). Guru dengan kebiasaan konsumsi junk food mempunyai risiko 3.2 kali lebih besar dibandingkan guru yang jarang konsumsi junk food selama stay at home dalam masa pandemi Covid-19.

Menurut Misra et al. ${ }^{41}$, bahwa pada beberapa negara berkembang khususnya di Asia Tenggara seperti di Indonesia ternyata meningkatnya risiko obesitas akibat faktor urbanisasi, konsumsi junk food berlebihan dan makanan olahan, serta aktivitas fisik yang kurang. Saat ini, konsumsi makanan cepat saji serta junk food telah menjadi sangat populer dan ini sangat erat kaitannya dengan obesitas. Sebuah studi dari Nurses' Health Study and Health Professionals Follow-Up Study telah menunjukkan bahwa konsumsi seperti kentang goreng, sosis, makan bersumber dari daging olahan atau makanan kaleng, daging bakar yang semuanya tersebut makanan gaya barat telah menghasilkan peningkatan berat badan yang siginifkan sehingga mengarah pada terjadinya obesitas ${ }^{42}$. Kebiasaan mengkonsumsi makanan junk food dapat menyebabkan hilangnya nutrisi penting serta cenderung meningkatkan lemak dalam tubuh. Junk food merupakan makanan dengan kadungan gizi rendah, tinggi zat yang tidak dibutuhkan tubuh seperti lemak trans, gula dan garam. Junk food umumnya jika tidak tinggi kandungan karbohidrat maka pasti tinggi kandungan lemak ${ }^{43}$. Sehingga dapat menambahkan lingkar pinggang, hal ini tentunya diperburuk bila wanita sangat jarang melakukan aktivitas fisik. Oleh karena itu, perlu sekali pola makan guru sekolah diatur dengan kandungan nutrisi yang seimbang dan melakukan olah raga secara rutin, sehingga guru sekolah wanita mempunyai stamina dan energi yang baik dalam beraktivitas selama pandemi Covid-19.

Tabel 6. Relevansi penyakit tidak menular (PTM) dengan risiko obesitas pada guru sekolah wanita

\begin{tabular}{|c|c|c|c|c|}
\hline \multirow{2}{*}{\multicolumn{2}{|c|}{ Penyakit Tidak Menular }} & \multicolumn{2}{|c|}{ Kejadian Obesitas pada Guru } & \multirow[t]{2}{*}{ Nilai $p$} \\
\hline & & \multirow{2}{*}{$\begin{array}{l}\text { Obesitas } \\
28(26.7 \%)\end{array}$} & Tidak Obesitas & \\
\hline Diabetes Melitus & $\mathrm{Ya}$ & & $35(21.2 \%)$ & 0.376 \\
\hline & Tidak & 77 (73.3 \%) & $130(78.8 \%)$ & \\
\hline \multirow[t]{2}{*}{ Hipertensi } & $\mathrm{Ya}$ & $50(47.6 \%)$ & $45(27.3 \%)$ & $0.001 *$ \\
\hline & Tidak & 55 (52.4 \%) & $120(72.7 \%)$ & \\
\hline \multirow[t]{2}{*}{ Kolesterol } & $\mathrm{Ya}$ & $24(22.9 \%)$ & $52(31.5 \%)$ & 0.161 \\
\hline & Tidak & $81(77.1 \%)$ & $113(68.5 \%)$ & \\
\hline \multirow[t]{2}{*}{ Radang Sendi } & $\mathrm{Ya}$ & $46(43.8 \%)$ & $50(30.3 \%)$ & $0.033^{*}$ \\
\hline & Tidak & 59 (56.2 \%) & $115(69.7 \%)$ & \\
\hline \multirow[t]{2}{*}{ Penyakit Jantung } & Ya & $16(15.2 \%)$ & $40(24.2 \%)$ & 0.104 \\
\hline & Tidak & 89 (84.8 \%) & $125(75.8 \%)$ & \\
\hline
\end{tabular}

Penelitian ini juga mengukur relevansi beberapa penyakit tidak menular (PTM) selama di berlakukannya social distancing berupa stay at home dan beraktivitas menjalankan pekerjaan di rumah saja (work from home, WFH) dengan risiko obesitas pada guru sekolah wanita di Kota Banda Aceh. Hasil penelitian (Tabel 6), menunjukkan bahwa tingginya proporsi obesitas pada guru sekolah wanita disertai dengan penyakit hipertensi dan radang sendi $(p<0,05)$. Hal ini disebakan belum tentu obesitas merupakan akibat penyakit hipertensi dan radang sendi, bisa jadi obesitas menyebabkan penyakit hipertensi dan radang sendi. Sehingga harapannya dengan tidak menjadi obesitas maka penyakit tidak menular menjadi tidak muncul. Selain itu diabetes, kolesterol dan penyakit jantung tidak mempunyai relevansi dengan risiko obesitas selama masa pandemi Covid-19 di Kota Banda Aceh.

Terkait beberapa masalah kesehatan dan risiko obesitas serta relevansinya dengan beberapa penyakit tidak menular, berdasarkan hasil penelitian telah menunjukkan bahwa kelebihan berat badan serta tingginya prevalensi obesitas telah menjadi endemi secara global. Hasil penelitian ini melaporkan bahwa obesitas pada guru wanita merupakan akibat dari masalah kesehatan seperti hipertensi dan radang sendi.
Hasil penelitian lain telah membuktikan bahwa peradangan sendi terutama pada bagian lutut adalah faktor risiko terhadap kejadian obesitas ${ }^{44}$. Selain itu, dengan meningkatnya IMT sesuai umur maka individu yang obesitas berdampak terhadap radang sendi yang jauh lebih parah dibandingkan individu yang mempunyai berat badan normal, dengan prevalensi lebih tinggi pada wanita dibandingkan pria. Studi tersebut menunjukkan hubungan signifikan antara laju IMT dengan risiko osteoartritis (peradangan sendi) baik pada bagian pinggul maupun bagian lutut ${ }^{45}$. Masa pandemi telah membuat banyak orang malas bergerak, dan ini berkaitan dengan tingginya kasus radang sendi. Sebuah penelitian menyarankan selama masa pandemi Covid-19 untuk menjalankan social distancing namun tetap berolah raga baik di rumah maupun dalam perkarangan rumah serta tetap mempertahankan pola makan yang sehat ${ }^{46}$.

Selain itu, kejadian obesitas khususnya obesitas pada orang dewasa selalu dikaitkan dengan hipertensi serta relevansinya dengan beberapa penyakit kardiovaskuler ${ }^{47}$. Telah diperkirakan bahwa dua pertiga dari prevalensi hipertensi secara langsung berkaitan dengan prevalensi obesitas ${ }^{48}$. Guru-guru sekolah memungkinkan mengalami masalah hipertensi akibat 
padatnya aktivitas dan faktor stres sehingga berdampak serius terhadap penyakit kardiovaskuler ${ }^{49}$. Menurut Mahamood et al. ${ }^{50}$ kejadian obesitas pada guru sekolah sangat terkait dengan tekanan darah mereka yang umumnya di atas $130 \mathrm{mmHg}$, tetapi kejadian hipertensi lebih besar pada guru laki-laki dibandingkan perempuan. Sebuah studi di Indonesia, juga melaporkan bahwa penyakit hipertensi tidak saja berdampak terhadap obesitas, namun juga erat kaitannya dalam patogenesis berbagai penyakit tidak menular lainnya seperti stroke, gagal jantung, kolesterol dan diabetes ${ }^{51}$. Dengan demikian semakin jelas bahwa konsekuensi dari penyakit hipertensi adalah meningkatnya berbagai macam penyakit tidak menular. Intervensi berupa penerapan gaya hidup positif seperti melakukan aktivitas fisik yang rutin untuk menjaga tubuh tetap sehat dan bugar, mengatur pola makan yang seimbang, mengurangi konsumsi junk food selama pandemi Covid-19 sangat memungkinkan dapat mengurangi penyakit kardiovaskuler maupun penyakit tidak menular lainnya ${ }^{52,53}$.

Penelitian ini mempunyai keterbatasan terkait dengan pengumpulan data, yaitu dilakukan secara online sehingga memungkinkan data-data yang diperoleh kurang objektif dalam memberikan fenomena dilapangan, namun peneliti berusaha melakukan valdasi data melalui telepon/email/sosial media. Selain itu, pengukuran data yang dilakukan secara Self Reported yaitu responden mengisi sendiri hasil pengukuran antropometri yang memungkinkan penggunaan alat timbangan, pengukur panjang dan pita ukur berbedabeda diantara setiap responden.

\section{KESIMPULAN}

Tingginya prevalensi obesitas pada guru sekolah wanita di Kota Banda Aceh akibat beberapa faktor risiko seperti faktor usia antara 40 - 50 tahun, ukuran lingkar pinggang $\geq 80 \mathrm{~cm}$, kebiasaan konsumsi junk food, tidak melakukan diet, serta kurangnya aktivitas fisik selama masa pandemi Covid-19. Faktor risiko paling dominan dan sebagai prediktor utama adalah kebiasaan konsumsi junk food. Selain itu, prevalensi obesitas pada wanita berkaitan dengan beberapa penyakit tidak menular seperti hipertensi dan radang sendi.

Saran, diperlukan program pendidikan gizi dan kesehatan kepada guru sekolah baik guru wanita maupun guru laki-laki yang berfokus pada berbagai pola hidup sehat, konsumsi makanan seimbang, kegiatan aktivitas fisik, serta pemeriksaan kesehatan berkala untuk menjaga tubuh tetap sehat dan bugar. Kegiatan tersebut dapat dilakukan melalui webinar, pelatihan-pelatihan, serta upaya promosi kesehatan pada era new normal dengan tetap memperhatikan dan menjalankan protokol kesehatan. Upaya-upaya tersebut diharapkan mampu untuk dapat mengurangi risiko penyakit kronis serta komorbiditas pada guru sekolah.

\section{ACKNOWLEDGEMENT}

Terima kasih diucapkan kepada tim pakar dari Politeknik Kesehatan Kemenkes Aceh atas kontribusi dan bimbingan dalam melakukan riset ini, dan Direktur Politeknik Kesehatan Kemenkes Aceh terkait izin penelitian, juga pihak sekolah yang telah memberikan izin dalam pelaksanaan penelitian. Ucapan terima kasih secara khusus disampaikan kepada guru sekolah wanita yang telah bersedia menjadi partisipan dalam penelitian ini.

\section{REFERENSI}

1. Fang, Y., Nie, Y. \& Penny, M. Transmission dynamics of the COVID-19 outbreak and effectiveness of government interventions: A data-driven analysis. J. Med. Virol. 92, 645-659 (2020).

2. Karin, O., Bar-On, Y. M., Milo, T., Katzir, I., Mayo, A., Korem, Y., Dudovich, B., Yashiv, E., Zehavi, A. J., \& Davidovich, N. Adaptive cyclic exit strategies from lockdown to suppress COVID-19 and allow economic activity. medRxiv Prescreen, 1-22 (2020).

3. Taghrir, M. H., Akbarialiabad, H. \& Marzaleh, M. A. Efficacy of mass quarantine as leverage of health system governance during COVID-19 outbreak: a mini policy review. Arch. Iran. Med. 23, 265-267 (2020)

4. Engle, S., Stromme, J. \& Zhou, A. Staying at home: mobility effects of covid-19. Available at SSRN (2020). doi:http://dx.doi.org/10.2139/ssrn.3565703

5. Lescure, F.-X., Bouadma, L., Nguyen, D., Parisey, M., Wicky, P.-H., Behillil, S., Gaymard, A., BouscambertDuchamp, M., Donati, F., \& Le Hingrat, Q. Clinical and virological data of the first cases of COVID-19 in Europe: a case series. Lancet Infect. Dis. (2020).

6. Ng, Y., Li, Z., Chua, Y. X., Chaw, W. L., Zhao, Z., Er, B., Pung, R., Chiew, C. J., Lye, D. C., \& Heng, D. Evaluation of the effectiveness of surveillance and containment measures for the first 100 patients with COVID-19 in Singapore--January 2-February 29, 2020. (2020).

7. Gugus Tugas Nasional. Kasus Positif COVID-19 Naik 1.031, Pasien Sembuh Meningkat Jadi 16.243. Gugus Tugas Percepatan Penanganan COVID-19 (Gugus Tugas Nasional) (2020). Available at: https://covid19.go.id/p/berita/kasus-positif-covid19-naik-1031-pasien-sembuh-meningkat-jadi16243. (Accessed: 18th June 2020)

8. Cuevas, A., Lim, S., Ryan, D., Clément, K. \& Heymsfield, S. In response to the current COVID-19 Pandemic, the World Obesity Federation and colleagues launched a series of webinars on COVID19 \& Obesity. WORLD OBESITY LIVE - COVID-19 AND OBESITY WEBINAR SERIES (2020). Available at: https://www.worldobesity.org/news/worldobesity-live-covid-19-and-obesity-webinar-series. (Accessed: 16th June 2020)

9. Di Renzo, L., Gualtieri, P., Pivari, F., Soldati, L., Attinà, A., Cinelli, G., Leggeri, C., Caparello, G., Barrea, L., \& Scerbo, F. Eating habits and lifestyle changes during COVID-19 lockdown: an Italian survey. J. Transl. Med. 18, 1-15 (2020).

10. Bhurosy, T. \& Jeewon, R. Overweight and obesity epidemic in developing countries: a problem with diet, physical activity, or socioeconomic status? Sci. World J. 2014, (2014).

11. WHO. World Health Statistics 2012. Global Health Observatory (GHO) data (2012). Available at: https://www.who.int/gho/publications/world_hea 
Ith_statistics/2012/en/. (Accessed: 26th May 2020)

12. Rachmi, C. N., Li, M. \& Baur, L. A. Overweight and obesity in Indonesia: prevalence and risk factors-a literature review. Public Health 147, 20-29 (2017).

13. Balitbangkes. Laporan Nasional Riskesdas Tahun 2018. (2018).

14. Sumar, W. W. T. Implementasi Kesetaraan Gender Dalam Bidang Pendidikan. J. Musawa IAIN Palu 7, 158-182 (2015).

15. Tuwu, D. Peran Pekerja Perempuan Dalam Memenuhi Ekonomi Keluarga: Dari Peran Domestik Menuju Sektor Publik. Al-Izzah J. Hasil-Hasil Penelit. 13, 63-76 (2018).

16. Monica, S. J. \& John, S. Risk Factors Contributing to Dyslipidemia among Female School Teachers. J. Krishna Inst. Med. Sci. 7, (2018).

17. Govind, K., Ratchagar, I. \& Ruby Violet Rani, E. Job Stress in Relation to Mental Health among the College Teachers. Annamalai Int. J. Bus. Stud. Res. 6, (2014).

18. Karikatti, S. S., Naik, V. A., Hallappanavar, A. B. \& Mallapur, M. D. Assessing Risk of Cardiovascular Disease among School Teachers: A High Risk Approach at School Settings. Indian J. Public Heal. Res. Dev. 7, 162-167 (2016).

19. Elmajnoun, H. K., Elhag, M. R. A., Mohamed, H., Haris, P. I. \& Abu-Median, A.-B. Ramadan 2020 in the Midst of the COVID-19 Pandemic: Guidance for Public Health. Library Learning Service, De Montfort University (De Montfort University, 2020).

20. Purwanto, A., Asbari, M., Fahlevi, M., Mufid, A., Agistiawati, E., Cahyono, Y., \& Suryani, P. Impact of Work From Home (WFH) on Indonesian Teachers Performance During the Covid-19 Pandemic: An Exploratory Study. Int. J. Adv. Sci. Technol. 29, 62356244 (2020).

21. Sintema, E. J. Effect of COVID-19 on the performance of grade 12 students: Implications for STEM education. Eurasia J. Math. Sci. Technol. Educ. 16, em1851 (2020).

22. Hastuti, J., Kagawa, M., Byrne, N. M. \& Hills, A. P. Determination of new anthropometric cut-off values for obesity screening in Indonesian adults. Asia Pac. J. Clin. Nutr. 26, (2017).

23. Badan Penelitian dan Pengembangan Kesehatan. Laporan Hasil Riset Kesehatan Dasar Tahun 2018. (Kementerian Kesehatan RI, 2018).

24. He, K., Hu, F. B., Colditz, G. A., Manson, J. E., Willett, W. C., \& Liu, S. Changes in intake of fruits and vegetables in relation to risk of obesity and weight gain among middle-aged women. Int. J. Obes. 28, 1569-1574 (2004).

25. Trisna, I. \& Hamid, S. Faktor-faktor yang berhubungan dengan obesitas sentral pada wanita dewasa (30-50 tahun) di Kecamatan Lubuk Sikaping Tahun 2008. J. Kesehat. Masy. Andalas 3, 68-71 (2009).

26. Hong, S. A., Peltzer, K., Lwin, K. T. \& Aung, L. S. The prevalence of underweight, overweight and obesity and their related socio-demographic and lifestyle factors among adult women in Myanmar, 2015-16. PLoS One 13, e0194454 (2018).

27. Buch, A., Carmeli, E., Boker, L. K., Marcus, Y., Shefer,
G., Kis, O., Berner, Y., \& Stern, N. Muscle function and fat content in relation to sarcopenia, obesity and frailty of old age-An overview. Exp. Gerontol. 76, 25-32 (2016).

28. Khotibuddin, M. Hubungan depresi dan perilaku makan terhadap berat badan lebih mahasiswa kedokteran. Mutiara Med. J. Kedokt. dan Kesehat. 17, 42-50 (2017).

29. Rocha, S. V., Cardoso, J. P., Santos, C. A. dos, Munaro, H. L. R., Vasconcelos, L. R. C., \& Petroski, E. L. Overweight/obesity in teachers: prevalence and associated factors. Rev. Bras. Cineantropometria Desempenho Hum. 17, 450-459 (2015).

30. Almandoz, J. P., Xie, L., Schellinger, J. N., Mathew, M. S., Gazda, C., Ofori, A., Kukreja, S., \& Messiah, S. E. Impact of COVID-19 Stay-at-Home Orders on Weight-Related Behaviors Among Patients with Obesity. Clin. Obes. e12386 (2020). doi:https://doi.org/10.1111/cob.12386

31. Haghighatdoost, F., Amini, M., Feizi, A. \& Iraj, B. Are body mass index and waist circumference significant predictors of diabetes and prediabetes risk: Results from a population based cohort study. World J. Diabetes 8, 365 (2017).

32. Abtahi, F., Naghshzan, A., Zibaeenezhad, M. J., Heydari, S. T., Khosropanah, S., Zamirian, M., Aghasadeghi, K., \& Moaref, A. The relationship between body mass index and pre-diabetes in teachers residing in shiraz-Iran 2009. Iran Cardiovasc Res J 4, 112-117 (2010).

33. Susetyowati, S., Huriyati, E., Kandarina, B. J. I., Muhammad, H. F. L. \& Faza, F. Prevalence and determinants of high blood glucose in urban and rural Indonesian adult population. Int. J. Diabetes Dev. Ctries. 39, 346-354 (2019).

34. Gupta, R., Ghosh, A., Singh, A. K. \& Misra, A. Clinical considerations for patients with diabetes in times of COVID-19 epidemic. Diabetes Metab. Syndr. 14, 211-212 (2020).

35. Puspa, A. Penyakit Komorbid Jadi Penyumbang Angka Kematian Pasien Covid-19. Humaniora Media Indonesia 1-2 (2020). Available at: https://mediaindonesia.com/read/detail/303934penyakit-komorbid-jadi-penyumbang-angkakematian-pasien-covid-19. (Accessed: 30th May 2020)

36. Deng, S.-Q. \& Peng, H.-J. Characteristics of and public health responses to the coronavirus disease 2019 outbreak in China. J. Clin. Med. 9, 575 (2020).

37. Ruan, Q., Yang, K., Wang, W., Jiang, L. \& Song, J. Clinical predictors of mortality due to COVID-19 based on an analysis of data of 150 patients from Wuhan, China. Intensive Care Med. 46, 846-848 (2020).

38. Min, J., Zhao, Y., Slivka, L. \& Wang, Y. Double burden of diseases worldwide: Coexistence of undernutrition and overnutrition-related noncommunicable chronic diseases. Obes. Rev. 19, 4961 (2018).

39. Rawal, L. B., Kanda, K., Mahumud, R. A., Joshi, D., Mehata, S., Shrestha, N., Poudel, P., Karki, S., \& Renzaho, A. Prevalence of underweight, overweight and obesity and their associated risk factors in 
Nepalese adults: data from a Nationwide Survey, 2016. PLoS One 13, e0205912 (2018).

40. Canaud, B., Kooman, J., Selby, N. M., Taal, M., Francis, S., Kopperschmidt, P., Maierhofer, A., Kotanko, P., \& Titze, J. Sodium and water handling during hemodialysis: new pathophysiologic insights and management approaches for improving outcomes in end-stage kidney disease. Kidney Int. 95, 296-309 (2019).

41. Misra, A., Singhal, N. \& Khurana, L. Obesity, the metabolic syndrome, and type 2 diabetes in developing countries: role of dietary fats and oils. $J$. Am. Coll. Nutr. 29, 289S-301S (2010).

42. Mozaffarian, D., Hao, T., Rimm, E. B., Willett, W. C. \& Hu, F. B. Changes in diet and lifestyle and longterm weight gain in women and men. N. Engl. J. Med. 364, 2392-2404 (2011).

43. Manolis, A. S. You are what you eat, hence curtail saturated and trans fats, free sugars and salt. Hosp. Chronicles 11, 65-76 (2016).

44. Kulkarni, K., Karssiens, T., Kumar, V. \& Pandit, H. Obesity and osteoarthritis. Maturitas 89, 22-28 (2016).

45. Wills, A. K., Black, S., Cooper, R., Coppack, R. J., Hardy, R., Martin, K. R., Cooper, C., \& Kuh, D. Life course body mass index and risk of knee osteoarthritis at the age of 53 years: evidence from the 1946 British birth cohort study. Ann. Rheum. Dis. 71, 655-660 (2012).

46. Mobasheri, A. COVID-19, osteoarthritis and women's health. Case reports women's Heal. e00207 (2020). doi:10.1016/j.crwh.2020.e00207
47. Zennaro, M.-C., Boulkroun, S. \& Fernandes-Rosa, F. An update on novel mechanisms of primary aldosteronism. J. Endocrinol. 224, R63-R77 (2015).

48. Jiang, S., Lu, W., Zong, X., Ruan, H. \& Liu, Y. Obesity and hypertension. Exp. Ther. Med. 12, 2395-2399 (2016).

49. Greiw, A. S. H., Gad, Z., Mandil, A., Wagdi, M. \& Elneihoum, A. Risk Factors for Cardiovascular Diseases among School Teachers in Benghazi, Libya. Ibnosina J. Med. Biomed. Sci. 2, (2010).

50. Mahamood, A., Vijayakumar, S., Pasula, S., Adepu, K. \& Laxmi, A. Relationship Between Waist Circumference and Body Mass Index of Hypertensionin Teaching Staff of Government and Private Schools. Int. J. Pharm. Sci. Lett. 3, 218-222 (2013).

51. Simbolon, D., Yorita, E. \& Talib, R. A. B. D. Consequences of Overweight and Obesity in Adolescence against the Risk of Hypertension in Adulthood. Kesmas Natl. Public Heal. J. 14, (2019).

52. Driggin, E., Madhavan, M. V, Bikdeli, B., Chuich, T., Laracy, J., Biondi-Zoccai, G., Brown, T. S., Der Nigoghossian, C., Zidar, D. A., \& Haythe, J. Cardiovascular considerations for patients, health care workers, and health systems during the COVID19 pandemic. J. Am. Coll. Cardiol. 75, 2352-2371 (2020).

53. Rios, S. da S., Chen, A. C. R. \& Chen, J. R. COVID-19: Does lifestyle intervention improve the course of the disease? A case series and literature review. Nutr. Diet. Prescreen, 1-16 (2020). 